\title{
Main pests of the elm (UImaceae) tree and their bioecological characteristics
}

\author{
Botirjon Sulaymonov ${ }^{1, *}$, Farrukh Yakubov ${ }^{1}$, and Azimjan Anorbaev ${ }^{1}$ \\ ${ }^{1}$ Tashkent State Agrarian University, University str., 2, Tashkent province, Uzbekistan, 100140
}

\begin{abstract}
This paper defines the types of elm trees pests in the Khorezm province in Uzbekistan, carries out their systematic analysis, and also determines the degree of their occurrence, as well as their natural types of enemies. The main phytophagous pests of elm trees in the Khorezm province belong to 4 genera and 14 species from 8 families. The vast majority of these pest species have been identified as Coleoptera pests. Pests were found to be mainly species that infect the body part of elm trees. In addition, 10 species of wild and parasitic entomophagous species have been identified as natural enemies. These species are phytophagous during the growing season and are important in managing their quantity.
\end{abstract}

\section{Introduction}

Elm trees belonging to the family Ulmaceae are a species that is widely used as ornamental and forest trees around the world and are resistant to various external factors. According to A.V.Gurudzinskaya, in the 19th-20th centuries, many trees belonging to the elm family grew in the Murgab River basin [1, 2]. According to V.P.Goloskokov, a total of 12 species of elm trees were introduced to Central Asia [2].

In the $30 \mathrm{~s}$ of the $20^{\text {th }}$ century the U.laevis type was introduced to Uzbekistan. A. Qayimov [1] conducted a selection of representatives of the elm trees resistant to Dutch disease. The main purpose of this selection work was to create disease-resistant elm varieties.

There are 13 species of elm in Uzbekistan, but the dendrological descriptions of the species sown by the population Ulmus procera Salisb., Ulmus fulva Michx., Ulmus uzbekistanica Litv., Ulmus laevis Pall., Ulmus scabra Mill., Ulmus densa Litv [3].

When growing elm, there are several of its pests and their diseases. In some areas, this is causing the complete extinction of the elm species. Pests belonging to the genus Coleoptera are particularly damaging. Coleoptera insects are found in a wide variety of entomofauna of the world, of which more than 360,000 species are considered dangerous to agriculture [4], members of this family make up $40 \%$ of all insects on earth, compared to $25 \%$ for living organisms [5]. Because most beetles are phytophagous, they cause great damage in agriculture, forestry, and horticulture. In terms of ecological and morphological diversity, it has always attracted the attention of entomologists and biologists $[4,6]$. Researchers are conducting phylogenetic and phylogeographic studies of coleopteran

\footnotetext{
* Corresponding author: b.sulaymonov@tdau.uz
} 
insects based on molecular markers [7]. GenBank stockpiles of this type of insect have been accumulated from such studies in recent years.

In Uzbekistan, leaf beetles (Coleoptera: Chrysomelidae) cause great damage as leaf pests of elm trees. Willow or elm leaf beetles (Galerucella luteola Mull.) are common among high-risk species $[1,7]$. Elm leaf beetles are a vicious pest of willow and ellm. The worms of the pest beetles eat the epidermal part of the tree leaves. As a result, the leaf falls off completely. The worms initially develop in clusters and then spread out. They emit an odor on themselves during feeding on the leaves. Females lay up to 500 eggs. Other species of Chrysomelidae can also be found in areas where leaf beetles are present. Because the ecological characteristics of these pests will be adapted to one group [2].

The Chrysomelidae family is one of the largest insects in the world, covering 35,000 species and 2,500 generations, and is a major pest of agriculture and forestry. One of these species, Chrysomela (= Melasoma), is one of the main and dangerous pests of the poplar [8, 9].

One of the main control measures in reducing the damage of this pest today is the chemical control method. However, biological control measures for the pest have a broader and longer-lasting mechanism of action than other methods. Unfortunately, data on natural enemies of the species Melosoma populi L. are insufficient [10]. But some researchers have given brief data on these. The entomophagous larvae of Teodorescu in Romania (1980), Zeki and Taurus in Turkey (1990) were introduced as Hexamermis albicans (Mermithidae) [11] and Linobia coccinellae (Hemisarcoptida) from the Tachinidae family as the parasitic entomophagous of the elm leaf beetles [12]. As a parasite of pupa, Schizonotus sieboldi (Ratz.) (Pteromalidae) is also one of the most common species [11]. In Kazakhstan, the common wild species Symmorphus murarius (L.) and Ancistrocerus nigricornis (Curt.) (Eumenidae) have been shown to be effective against leafhoppers [12].

Elm leaf beetle (Gallerucella luteola Muel.), willow leaf beetle (Pyrrhalta luteolla) species are found in the country, and their damage is high. Poplar leaf beetle (Melasoma (Chrysomela) populi) is one of the most dangerous pests of young poplar, willow and elm in the forests of our country. Widespread in forest and foothills. The period of mass hatching of larvae of the pest is observed in the second decade of May. The pest is widespread in CIS countries, Southern Europe, China, Korea, Japan and India and is registered as the main pest of ornamental trees [2]. The elm leaf beetle (Gallerucella luteola Muel.) Is widespread in all regions of Central Asia. The pest mainly infects willow and elm leaves, the affected leaves fall off $[10,13]$.

Apigeros leucopoda Takeuchi (Hymenoptera: Argidae), a zigzag-forming pest native to East Asian countries, has been reported to be the main pest in Europe, Poland and Hungary (Blank et al., 2010). Since 2003, this pest has caused significant damage in several countries of the continent. The pest mainly causes damage to Siberian elm (Ulmus pumila L.), a condition that affects large areas in Hungary, Italy and Russia $[1,2,7,8,14,15]$. The main reasons for its arrival in Europe are still unknown, there are cases of extinction of elm trees in the European part of Russia.

In addition, the Siberian elm tree in some regions of Europe is likely to become extinct due to this pest. In addition, these elm plantations are prone to damage due to drought, bark beetle Scolytus kirschii (Coleoptera: Curculionidae) [14].

In the conditions of our country, leaf pests and their damage in ornamental forest trees are relatively little studied. For this reason, studies have been conducted in Khorezm province to study the pests of the elm tree and to study their bioecological indicators such as damage, level of development, distribution and changes in population size. 


\section{Materials and methods}

The research was conducted in 2019-2020 in Khorezm province of the country on the types, biology and level of development of elm pests. The laboratory of the Department of Plant Protection of Tashkent State Agrarian University was used in the research. The territory of Khorezm province consists of low plains and small hills.

Geographically, it is located between $40^{\circ}-42^{\circ}$ north latitude and $60^{\circ}-62^{\circ}$ east longitude, with a dry climate and ornamental trees, mainly elm, willow and poplar. Identification of damaged elm trees in the area and development of body, leaf pests were carried out from March to November. In the registration of elm pests, methods of N. G. Kim, B. A. Dospekhov, and I. K. Makhnovsky [1, 2] were used. The degree and type of pest infestation were determined, samples were collected from them, and samples were systematically analyzed in the laboratory.

Data on the exit from wintering and the number of pests were collected from trees and delivered to the laboratory, where their development and species were systematically analyzed. In laboratory studies, a thermostat MEMMERT IPP IPP 55 plus, a microscope XSZ-152 s type in the separation of morphological features, $70 \%$ alcohol-based liquid for the storage of insect samples were used. In late April and early May, the eggs and larvae of the beetles were collected and they were additionally fed in special glass containers. In studying the development of the pest in the field, the relative humidity and air temperature were noted separately.

\section{Results and discussion}

The study identified the species of elm in the Khorezm province, their levels of pest infestation and pest species. Initially, research was conducted on leaf pests and body pests, their entomophagous species. Samples were collected from all the pests encountered in the elm tree and their species were systematically analyzed under laboratory conditions.

According to it, samples were collected from elm leaf pests, all samples were studied during the growing season, the amount of damage to trees, the period of damage to trees, its entomophagous species. Detected pests were found not only in elm, but also in ornamental trees of adjacent species, the degree of infestation of these pests varied. The study showed that in 2019-2020, the levels of infestation varied by species of the pest, and the population size of some of them was consistently high. It was found that this process also depends on weather variability. The main phytophagous pests identified in the study belonged to 14 genera belonging to 4 genera and 8 families. There were also a few rare species of bugs. However, the reason for their lack of economic risk was not recorded. The listed elm leaf pests include the Coleopterans of the Chrysomelidae family, the elm leaf beetles (Galerucella luteola Muell.), willow leaf beetles (Pyrrhalta luteolla L.), Lepidopterans of Geometridae family Mulberry moth (Apocheima cinerarius Ersch.), Homopterans of Pemphigidae family elm sack gall aphid (Bursocrypta (Tetraneura) ulmi L.), Tetraneura coemlescens (Tetraneura coerulescent Pass) and in some areas the leaves have been completely destroyed. Leaf beetles are mainly found in the spring, and their populations fluctuated throughout the season.

Among the hemipteran pests was also found the manniferous cicada (Cicada ulmi Linnaeus) of the family Cicadidae. Although the population size of this pest is not high during the season, damage has been observed in the foothills. Another family of lepidopteran pests, Cossidae, goat moth (Cossus cossus L.), has a higher population size and higher infestation rates than other pests. The pest is mainly found on trees in perennial and drought areas. 
In addition, several species of the Scolytidae family belonging to the genus Coleoptera have been identified as elm body pests. Of these bark beetles, the elm bark beetle (Scolytus kirschi Scol), large elm bark beetle (Scolytus scolytus Fabr), smaller elm bark beetle (Scolytus multistriatus Mareh), shothole borer (Scolytus rugulosus Ratl.), eastern bark beetle (Scolytus erienfalis Fgg) are common and have been shown to cause great damage, especially to old tree trunks. These types of pests are constantly evolving in season, and the bulk of their lives are hidden. In arid regions, it is more common than in other regions (Table 1).

Table 1. Elm tree pests and their entomophagous species (2019-2020).

\begin{tabular}{|c|c|c|c|c|c|}
\hline \# & Type of pests & 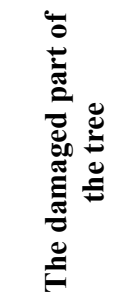 & 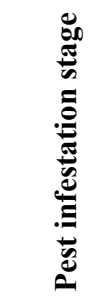 & 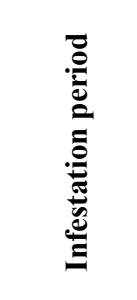 & 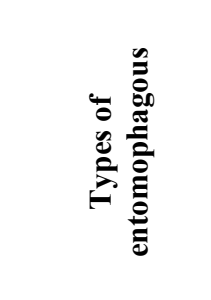 \\
\hline \multicolumn{6}{|c|}{ Coleoptera:Chrysomelidae } \\
\hline 1 & $\begin{array}{c}\text { Elm leaf beetle } \\
\text { (Galerucella luteola Muell.) }\end{array}$ & Leaf & $\begin{array}{c}\text { Beetle, } \\
\text { larva }\end{array}$ & $\begin{array}{l}\text { spring, } \\
\text { summer }\end{array}$ & $\begin{array}{l}\text { Lydell niqripes } \\
\text { Fall. }\end{array}$ \\
\hline 2 & $\begin{array}{c}\text { Willow leaf beetle } \\
\text { (Pyrrhalta luteolla } \mathrm{L} .)\end{array}$ & Leaf & $\begin{array}{c}\text { Beetle, } \\
\text { larva }\end{array}$ & $\begin{array}{l}\text { spring, } \\
\text { summer }\end{array}$ & $\begin{array}{l}\text { Lydell niqripes } \\
\text { Fall. }\end{array}$ \\
\hline \multicolumn{6}{|c|}{ Lepidoptera:Geometridae } \\
\hline 1 & $\begin{array}{l}\text { Mulberry moth (Apocheima } \\
\text { cinerarius Ersch.) }\end{array}$ & Leaf & Larva & Spring & $\begin{array}{l}\text { Elosmus } \\
\text { albipenns } \\
\text { Thomson. }\end{array}$ \\
\hline \multicolumn{6}{|c|}{ Homoptera: Pemphigidae } \\
\hline 1 & $\begin{array}{c}\text { Elm sack gall aphid } \\
\text { (Bursocrypta (Tetraneura) } \\
\text { ulmi L.) }\end{array}$ & Leaf & $\begin{array}{l}\text { Imago, } \\
\text { larva }\end{array}$ & Spring & $\begin{array}{c}\text { Coccinella } \\
\text { septempunctata } \\
\text { L., Chrysopa } \\
\text { septempunctata } \\
\text { Wesm. } \\
\end{array}$ \\
\hline 2 & $\begin{array}{c}\text { Tetraneura coemlescens } \\
\text { (Tetraneura coerulescent } \\
\text { Pass) }\end{array}$ & Leaf & $\begin{array}{l}\text { Imago, } \\
\text { larva }\end{array}$ & Spring & $\begin{array}{c}\text { Coccinella } \\
\text { septempunctata } \\
\text { L., Chrysopa } \\
\text { septempunctata } \\
\text { Wesm. }\end{array}$ \\
\hline \multicolumn{6}{|c|}{ Hemiptera:Cicadidae } \\
\hline 1 & $\begin{array}{c}\text { Manniferous cicada (Cicada } \\
\text { ulmi Linnaeus ) }\end{array}$ & Leaf & $\begin{array}{l}\text { Imago, } \\
\text { larva }\end{array}$ & $\begin{array}{l}\text { Summer, } \\
\text { autumn }\end{array}$ & $\begin{array}{c}\text { Coccinella } \\
\text { septempunctata } \\
\text { L., Chrysopa } \\
\text { septempunctata } \\
\text { Wesm. }\end{array}$ \\
\hline \multicolumn{6}{|c|}{ Lepidoptera: Cossidae } \\
\hline 1 & $\begin{array}{l}\text { Goat moth (Cossus cossus } \\
\text { L.) }\end{array}$ & Body & Larva & $\begin{array}{l}\text { Througho } \\
\text { ut the } \\
\text { season }\end{array}$ & - \\
\hline & \multicolumn{5}{|c|}{ Coleoptera: Scolytidae } \\
\hline 1 & $\begin{array}{c}\text { Elm bark beetle (Scolytus } \\
\text { kirschi Scol) }\end{array}$ & $\begin{array}{l}\text { Branches, } \\
\text { body }\end{array}$ & $\begin{array}{l}\text { Imago, } \\
\text { larva }\end{array}$ & $\begin{array}{l}\text { Througho } \\
\text { ut the } \\
\text { season }\end{array}$ & $\begin{array}{l}\text { Dendrasoter } \\
\text { protuberans }\end{array}$ \\
\hline 2 & $\begin{array}{l}\text { Large elm bark beetle } \\
\text { (Scolytus scolytus Fabr) }\end{array}$ & $\begin{array}{l}\text { Branches, } \\
\text { body }\end{array}$ & $\begin{array}{l}\text { Imago, } \\
\text { larva }\end{array}$ & $\begin{array}{l}\text { Througho } \\
\text { ut the }\end{array}$ & $\begin{array}{c}\text { Microefus } \\
\text { tumidulus Nees. }\end{array}$ \\
\hline
\end{tabular}




\begin{tabular}{|c|c|c|c|c|c|}
\hline 3 & $\begin{array}{c}\text { Smaller elm bark beetle } \\
\text { (Scolytus multistiatus } \\
\text { Mareh) }\end{array}$ & $\begin{array}{c}\text { Branches, } \\
\text { body }\end{array}$ & $\begin{array}{c}\text { Imago, } \\
\text { larva }\end{array}$ & $\begin{array}{c}\text { Througho } \\
\text { ut the } \\
\text { season }\end{array}$ & $\begin{array}{c}\text { Aspidocolpus } \\
\text { carinatoz Nels. }\end{array}$ \\
\hline 4 & $\begin{array}{c}\text { Shothole borer (Scolytus } \\
\text { zugulosus } \text { Ratl. })\end{array}$ & $\begin{array}{c}\text { Branches, } \\
\text { body }\end{array}$ & $\begin{array}{c}\text { Imago, } \\
\text { larva }\end{array}$ & $\begin{array}{c}\text { Througho } \\
\text { ut the } \\
\text { season }\end{array}$ & $\begin{array}{c}\text { Entedon tenuitaris } \\
\text { Thoms. }\end{array}$ \\
\hline 5 & $\begin{array}{c}\text { Eastern bark beetle } \\
\text { (Scolytus erienfalis Fgg) }\end{array}$ & $\begin{array}{c}\text { Branches, } \\
\text { body }\end{array}$ & $\begin{array}{c}\text { Imago, } \\
\text { larva }\end{array}$ & $\begin{array}{c}\text { Througho } \\
\text { ut the } \\
\text { season }\end{array}$ & $\begin{array}{c}\text { Entedon tenuitaris } \\
\text { Thoms. }\end{array}$ \\
\hline 1 & $\begin{array}{c}\text { Cratomerus intermedius } \\
\text { (Cratomerus intermedius } \\
\text { Obenb.) }\end{array}$ & $\begin{array}{c}\text { Branches, } \\
\text { body }\end{array}$ & Larva & $\begin{array}{c}\text { Througho } \\
\text { ut the } \\
\text { season }\end{array}$ & $\begin{array}{c}\text { Cryptus } \\
\text { insinuatar Gr }\end{array}$ \\
\hline 1 & $\begin{array}{c}\text { Coleoptera:Buprestidae } \\
\text { (Aeolesthes sarta Solsky.) }\end{array}$ & Coleoptera: Cerambycidae \\
\hline
\end{tabular}

Bark beetles have been found to cause severe damage to large branches, mainly in the trunk. Because these species of pests are close to each other in harm and biological properties, they have been found to occur mainly together. The smaller elm bark beetle (Scolytus multistiatus Mareh) is more common than other species and has been found to cause significant damage to adjacent trees as well. However, another representative of the Buprestidae family of coleopteran pests, the Cratomerus intermedius (Cratomerus intermedius Obenb.) was identified. Although the damage from these beetles is not high, it was found that they develop by the end of the season and cause severe damage to some species of elm. The development of beetles is variable over the years. It has been found that almost all of the developmental stages take place in the body part of the elm tree. At the same time, the City longhorn beetle (Aeolesthes sarta Solsky.) was encountered as the most basic and economically high pest of pine trees. Due to the high number of beetles, its worms were also doubled, and it was found that the worms infected with this pest by almost 1 in 5 of elm. City longhorn beetles were more common in trees in water-scarce areas, and more common in elm and willow trees than other species. It has been found to be more common, especially in trees older than 15-20 years.

In addition to the pests identified above, several of their entomophagous species have also been identified. These entomophagous are considered important in reducing the number of pests. The Lydell niqripes Fall species of the Tachinid fly has been found in large numbers as a parasitic enemies of the elm trees, Elosmus albipenns Thomson of the mulberry moth parasite, as well as Coccinella septempunctata L., Chrysopa septempunctata Wesm from wild entomophagous species have also been found to feed on other types of phytophagous insects. Dendrasoter protuberance type of nematode as entomophagous of bark beetles, as well as Microefus tumidulus Nees Aspidocolpus carinatoz Nels, Chiropochys colon L, Entedon tenuitaris Thoms species of parasitic insects were found to be actively involved in pest control.

Entomophages were less observed in season than pest numbers, and they were found to increase, especially in the fall. The parasite of Cratomerus intermedius beetles, Cryptus insinuatar Gr, and the species of Sclerodermus turkmenicus were also found as parasites of the City longhorn beetle. However, their low incidence rate and low activity in pest control were found to be low. The development of pests identified in the elm tree was mainly seasonal, and their quantities varied according to the ecological environment. In the study, separate studies were conducted on the seasonal variability and reciprocal size of the 
population of this species of insects. In this case, the development of phytophagous, their amount in a single elm tree varies. As a species with a higher prevalence than other pests, the elm leaf beetle (Galerucella luteola Muell.) accounted for $11.2 \%$ and the willow leaf beetle (Pyrrhalta luteolla L) for 9.2\%. Elm leaf beetles were found to have a high population size during the season.

At the same time, goat moth (Cossus cossus L.) was found in $14.7 \%$ of cases compared to other species of pests, and this pest also had a higher amount and damage than other species. In addition, the City longhorn beetle (Aeolesthes sarta Solsky.) was found in $12.3 \%$ of the total pests as a species that is common in elm tree species and caused the drying of some trees (Figure 1).

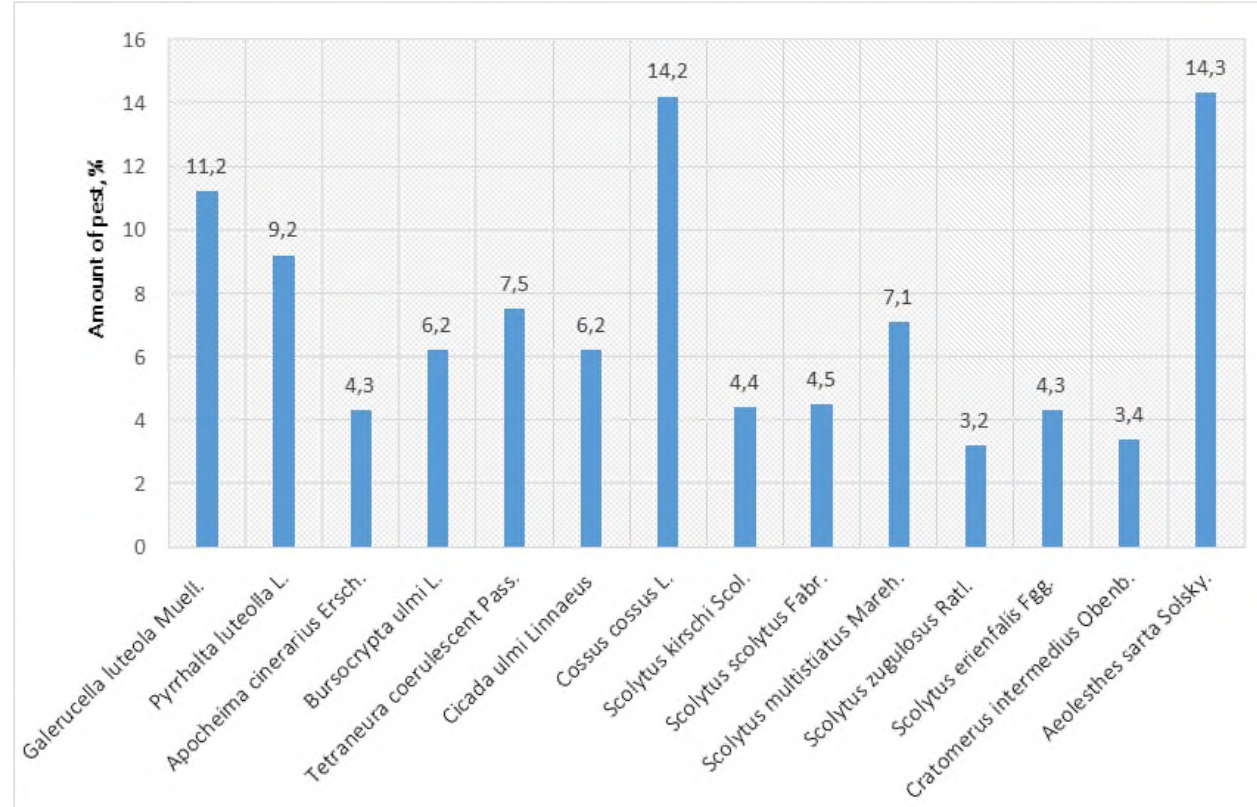

Fig. 1. The degree of damage to trees by common pests of elm trees (2019-2020)

Other types of phytophagous were found to average $6.1-2.1 \%$, and although their high level of economic risk was not observed, these pests were consistently identified as companion pests. According to the incidence rate of the pest and the amount of pest, a higher level of pest was recorded than that of other species of leaf beetles, goat moth and city longhorn beetle. The ecological environment of Khorezm province and high levels of pest infestation of elm species were observed. This leads to a sharp decline in the number of trees of this species and a negative impact on the ecological environment of the region. Of the 2,411 elm trees analyzed, 409 (17\%) were found to have died as a result of body pests. Others are damaged to varying degrees. As a result, it was observed that the trees grew and changed their shape. In particular, most of the identified pests were noted as phytophagous, well-adapted to the xerophilic environment. Based on the data on the phytosanitary condition of elm trees, it was found that the number of body pests is higher than that of leaf pests, as well as their damage. At the same time, it was found that the pests were mainly affected to a greater extent by the older trees.

In the study, elm pests were identified and systematically analyzed according to the climate of Khorezm province and its other factors. The results revealed that most of the 
pests encountered on the elm trees are body pests. It was also found that the pest infested more strongly in some areas with poor water supply. Khorezm province, compared to other regions, is a region where ancient and valuable elm species grow well. But in the last 10 years, a large proportion of elm trees have died under the influence of pests. In addition, the proximity of the groundwater level of the area, the high level of alkalinity makes it difficult to develop other types of trees. Of the pests, the city longhorn beetles and the goat moth pests are more numerous than other species, indicating a high level of environmental problems in the area. In addition, the high prevalence of bark beetles in the area compared to other types of forest pests indicates the xerophilicity of the area.

\section{Conclusion}

As a pest of elm, the main phytophagous pests were identified in 4 genera, 14 species belonging to 8 families. Most of these pests were found to be coleopteran pests. In addition, according to the degree of extinction and infestation of elm trees, it was found that the species of pests are mainly well adapted to the xerophilic environment. Changes in the ecological environment of the region and the proximity of groundwater also affect the variability of pest numbers. In addition to phytophagous species, entomophagous species that control their numbers have also been found. At the same time, 10 species of predatory and parasitic entomophagous were identified, and these species also developed seasonally.

\section{References}

1. A. K. Qayimov, E. T. Berdiev, Dendrology, 336 (Cholpon Press, Tashkent, 2012)

2. B. Sulaymonov, NMIU of Uzbekistan, 79-83 (2017)

3. S. M. Blank, H. Hara, J. Mikulas, European Journal of Entomology 107, 357-367 (2010)

4. S. M. Blank, T. Kohler, T. Pfannenstill, Journal of Hymenoptera Research 41, 57-74 (2014)

5. R. Haitlinger, Przegląd Zoologiczny 43, 181-182 (1999)

6. T. Hunt, J. Bergsten, Z. Levkanicova, A. Papadopoulou, O. S. John, R. Wild, P. M. Hammond, D. Ahrens, M. Balke, M. S. Caterino, Science 318, 1913-1916 (2007)

7. L. A. Lengesova, Priroda Simbirskogo Povolzh'ya 13, 136-139 (2012)

8. T. P. Marikovskaja, T. I. Šterbakova, Zaštita Rastenij 6, 29-31 (1989)

9. M. Yaman, Iran J Parasitol 13(2), 244-250 (2018)

10. V. I. Shchurov, Y. I. Grinenko, N. A. Lengesova, M. Y. Grinenko, Zashchita i karantin rasteniy 2, 37-39 (2012)

11. G. Vetek, D. Bartha, R. Olah, Periodicum Biologorum 119, 101-106 (2017)

12. A. Mecke, I. Lee, J.R. Baker jr., M.M. Banaszak Holl, B.G. Orr, Eur. Phys. J. E 14, 7 (2004)

13. M. Ben Rabha, M.F. Boujmil, M. Saadoun, B. Bessaïs, Eur. Phys. J. Appl. Phys. (to be published)

14. F. De Lillo, F. Cecconi, G. Lacorata, A. Vulpiani, EPL, 84 (2008)

15. L. T. De Luca, Propulsion physics (EDP Sciences, Les Ulis, 2009) 